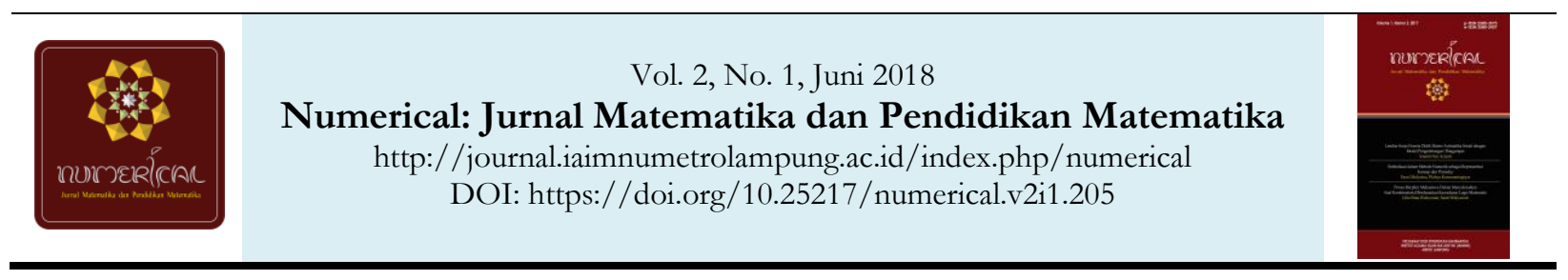

\title{
Implementasi Kurikulum KKNI Pada Program Studi Matematika Universitas Islam Negeri Raden Intan Lampung
}

\author{
R. Masykur ${ }^{1}$, Undang Rosidin², Agung M. Iqbal ${ }^{3}$ \\ 1,2,3 Universitas Islam Negeri Raden Intan Lampung, Indonesia \\ Correspondence: $\square$ rmasykur@yahoo.co.id
}

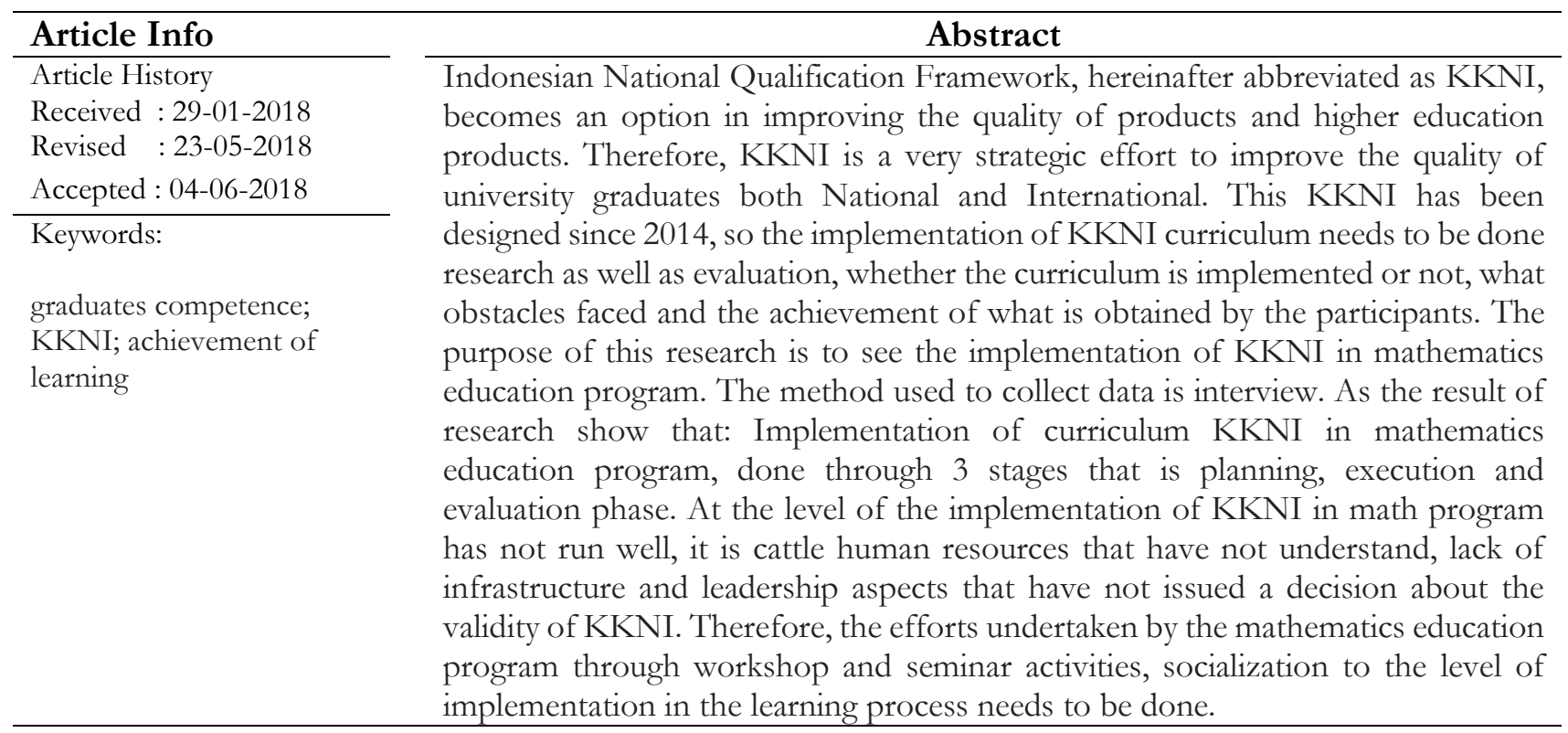

\section{PENDAHULUAN}

Pendidikan adalah sarana untuk menuju kepada pertumbuhan dan perkembangan bangsa. Pendidikan merupakan investasi jangka panjang yang memiliki nilai strategis bagi kelangsungan peradaban manusia di dunia [1]. Undang-Undang Republik Indonesia nomor 2 tahun 2009 dalam Sukring menjelaskan bahwa pendidikan merupakan usaha sadar dan terencana untuk mewujudkan suasana belajar dan proses pembelajaran agar peserta didik secara aktif mengembangkan potensi dirinya untuk memiliki kekuatan spiritual keagamaan, pengendalian diri, kepribadian, kecerdasan, akhlak mulia, serta keterampilan yang diperlukan dirinya, masyarakat, bangsa, dan negara [2]. Pendidikan salah satu setting utama dalam partisipasi kegiatan pembelajaran kooperatif [3]. Maka dari itu pendidikan menjadi salah satu modal penting untuk memajukan sebuah bangsa karena kesejahteraan dan kemajuan sebuah bangsa dapat dilihat dari tingkat pendidikannya. Pendidikan memegang peranan penting dalam menciptakan individu berkualitas [3]. Dunia pendidikan senantiasa mengalami perubahan yang terus menerus dari tahun ke tahun [3]. Pada dasarnya tujuan dari kegiatan pendidikan adalah untuk membantu para generasi memaksimalkan potensi dirinya, agar mampu menghasilkan generasi yang mampu berdaya saing dizaman berkembangnya ilmu pengetahuan serta teknologi yang ada.

Seiring dan sejalan dengan perkembangan ilmu dan teknologi saat ini, maka dampaknya terjadi dalam kehidupan manusia sehari-hari di mana dapat kita lihat berbagai macam alat komunikasi semakin berkembang, layanan transportasi semakin canggih, kebutuhan manusia semakin terlayani dengan cepat 
dan tepat, hubungan satu sama lain hampir tidak ada batasnya, begitu mudah manusia untuk mendapatkan dan mengaksesnya [6]. Melihat kenyataan ini, kehadiran perguruan tinggi di era ini diharapkan untuk melahirkan keluaran yang berkualitas dan berdaya saing kuat, upaya memenuhi berbagai tuntutan dan kebutuhan manusia akan ilmu pengetahuan, lapangan kerja atau mamasuki dunia kerja. Guru ideal akan terwujud jika latar belakang kemampuan akademiknya baik [7]. Dengan demikian perguruan tinggi dituntut untuk melakukan terobosan-terobosan yang positif dan mengedapankan kepentingan masyarakat sebagai pengguna lulusan [8]. Salah satunya terobosan itu adalah mengimplementasikan kurikulum berbasis KKNI.

Kehadiran KKNI sebenarnya merupakan acuan umum bagaimana kualifikasi seseorang mendapat pengakuan di dunia kerja. Kebutuhan Indonesia untuk segera memiliki KKNI sudah sangat mendesak mengingat tantangan dan persaingan global pasar tenaga kerja nasional maupun internasional semakin terbuka. Pergerakan tenaga kerja dari dan ke Indonesia tidak lagi dapat dibendung dengan peraturan atau regulasi yang bersifat protektif. Agar dalam jangka pendek dan jangka panjang Indonesia mampu bertahan tetapi tetap bergerak maju di arena ekonomi global, maka pengakuan timbal balik dan setara dengan negara asing menjadi butir-butir yang kritis dalam pengembangan suatu kerangka kualifikasi tenaga kerja nasional [9]. Ada tiga strategi pengembangan KKNI. Pertama, KKNI menganut strategi kesetaraan kualifikasi seseorang yang diperoleh dari dunia pendidikan formal, nonformal, informal dan pengalaman bekerja. Kedua, KKNI mengakui kualifikasi pemegang ijazah yang akan bekerja maupun melanjutkan pendidikan di luar negeri, pertukaran pakar dan mahasiswa lintas negara atau pemegang ijazah dar luar negeri yang bekerja di Indonesia. Ketiga, KKNI mengakui kesetaraan kualifikasi capaian pembelajaran berbagai bidang keilmuan pada tingkat pendidikan tinggi, baik yang berada pada jalur pendidikan akademik, vokasi, profesi, serta melalui pengembangan karir yang terjadi di strata kerja, industri atau asosiasi profesi [10] .

Perguruan Tinggi dalam hal ini adalah Universitas Islam Negeri Raden Intan lampung, Fakultas Tarbiyah dan Keguruan dituntut untuk melakukan perubahan secara mendasar. Salah satu bentuk perubahan-perubahan dimulai dari merumuskan ide yang dituangkan dalam bentuk visi, misi dan program yang terukur dan lebih mengedepankan kebutuhan hari ini dan yang akan datang. Salah satu program yang sudah dirumuskan untuk memenuhi kebutuhan baik para mahasiswa maupun pengguna lulusan adalah implementasi kurikulum berbasis KKNI pada pengembangan kurikulum di setiap program studi [11]. Hal ini dimaksudkan sebagai upaya untuk menyelaraskan mutu dalam penjenjangan antara lulusan Perguruan Tinggi Islam dengan kriteria kualifikasi lulusan seperti yang diharapkan pengguna (stakeholders) [12]. Oleh karena itu, pengembangan kurikulum di Perguruan Tinggi Islam yang merujuk pada KKNI merupakan suatu upaya yang sangat strategis untuk meningkatkan mutu lulusan Perguruan Tinggi Islam baik skala nasional maupun internasional. KKNI ini sudah dirancang sejak tahun 2014, sehingga implementasi kurikulum KKNI ini perlu dilakukan penelitian sekaligus sebagai evaluasi, apakah kurikulum ini terlaksana atau tidak, hambatan apa yang dihadapi dan pencapaian apa yang diperoleh oleh para peserta didik (mahasiswa).

Atas dasar pemikiran dan luasnya kajian tentang implementasi kurikulum KKNI di Fakultas Tarbiyah dan Keguruan Universitas Islam Negeri Raden Intan lampung, maka peneliti membatasi lingkup penelitiannya yaitu: program studi pendidikan matematika Fakultas Tarbiyah dan Keguruan. Adapun tujuan yang ingin dicapai dalam penelitian ini adalah untuk mengetahui mengenai implementasi kurikulum KKNI pada Prodi Pendidikan Matematika Fakultas Tarbiyah dan Keguruan. Peneliti ingin menemukan terkait dengan pemahaman, tanggapan dosen dan mahasiswa terhadap Implementasi Kurikulum KKNI 
pada Prodi Pendidikan Matematika Fakultas Tarbiyah dan Keguruan dalam proses pembelajaran terutama mata kuliah strategi pembelajaran.

\section{METODE PENELITIAN}

Jenis penelitian ini bersifat deskriptif analisis, yaitu penelitian yang semata-mata hanya mendeskripsikan keadaan dan kejadian atas suatu obyek, diuraikan secara lengkap, rinci, jelas, dan sistematis. Subjek utama dalam penelitian ini adalah dosen dan mahasiswa program studi pendidikan matematika yang diambil secara acak. Objek penelitiaan merupakan variabel-variabel yang menjadi perhatiaan peneliti yang dalam hal ini yaitu implementasi kurikulum KKNI di Prodi Matematika Fakultas Tarbiyah dan Keguruan Universitas Islam Negeri Raden Intan Lampung. Teknik pengumpulan data yang digunakan dalam penelitian ini adalah observasi dan wawancara. Analisa data dilakukan terhadap berbagai sumber, yang dihasilkan dari observasi, wawancara, dokumen resmi, gambar, foto, dan sebagainya. Analisis dilakukan secara bersamaan mencakup tiga kegiatan 1) Reduksi data; 2) Penyajian data; 3) Penarikan kesimpulan [13]. Data dapat dikatakan absah manakala dihasilkan dari proses 1) kredibilitas (validitas internal); 2) transferdibilitas (validitas eksternal); 3) depenabilitas (realibitas); 4) konfirmabilitas [14].

\section{HASIL DAN PEMBAHASAN}

Hasil penelitian implementasi KKNI pada prodi pendidikan matematika disajikan dalam bentuk hasil wawancara. Wawancara dilakukan kepada ketua jurusan, dosen dan mahasiswa. Secara keseluruhan jawaban responden dapat dirumuskan sebagai berikut.

Hasil penelitian wawancara pertama tentang pengertian KKNI, responden mengatakan bahwa Kerangka Kualifikasi Nasional Indonesia yang selanjutnya disingkat KKNI, adalah kerangka penjenjangan kualifikasi kompetensi yang dapat menyandingkan, menyetarakan, dan mengintegrasikan antara bidang pendidikan dan bidang pelatihan kerja serta pengalaman kerja dalam rangka pemberian pengakuan kompetensi kerja sesuai dengan struktur pekerjaan di berbagai sektor.

Hasil wawancara ke dua tentang Apakah KKNI ini cocok diterapkan di perguruan tinggi, jawaban mereka Kurikulum program studi di perguruan tinggi, dituntut untuk merevisi berdasarkan Kerangka Kualifikasi Nasional Indonesia (KKNI) yang terbit berdasarkan Peraturan Presiden (PP) Nomor 8 Tahun 2012. Dalam KKNI terdapat level 1-9 dan menjadi acuan untuk pembangunan sumber daya manusia dan tenaga kerja Indonesia dengan pengakuan kualifikasi tidak hanya mengacu pada pendidikan formal, tetapi juga pelatihan yang didapat di luar pendidikan formal, pembelajaran mandiri, dan pengalaman kerja. Oleh karena itu KKNI sangat cocok untuk diterapkan pada perguruan tinggi baik negeri ataupun swasta.

Hasil wawancara ketiga tentang apakah KKNI sesuai dengan kebutuhan pengguna lulusan yaitu masyarakat, industri dan lapangan kerja, jawaban mereka Kurikulum KKNI sangat sesuai dengan kebutuhan pengguna lulusan yaitu masyarakat, industri dan lapangan kerja. Hal ini didasari dari pemikiran bahwa kurikulum KKNI dapat membentuk lulusan dengan mental kerja yang kuat dan siap kerja di lapangan dan siap ditempatkan daerah manapun termasuk di daerah tertinggal. Lulusan mahasiswa sekarang belum matang mental dan belum siap kerja, dan tempat kerja maunya di kota, maunya pakai dasi, kerja dikantoran dan gaji tinggi. Memiliki kemampuan manajerial dan kemampuan teknis serta pengetahuan teori yang luas. Memiliki jiwa enterpreneurship, siap praktek dan skill mumpuni. Mengusai literasi bahasa inggris dan analisis data serta memahami teknik alat teknologi, Memiliki inisiatif kerja dan 
terampil dalam bekerja serta tidak menunggu kerja atau perintah. Memiliki sikap disiplin, mempunyai ide dan gagasan yang bermanfaat bagi dunia kerja.

Hasil wawancara ke empat tentang apa saja ruang lingkup KKNI, jawaban meraka ruang lingkup kurikulum KKNI harus mengacu pada ruang lingkup standar nasional yang terdiri dari Ruang Lingkup Standar Nasional Pendidikan dan Pengabdian. Hasil wawancara ke lima tentang apakah KKNI sudah dilaksanakan di program studi matematika, mereka menjawab bahwa walaupun prodi pendidikan matematika Fakultas Tarbiyah dan Keguruan UIN Raden Intan Lampung telah siap dengan semua instrument penerapan KKNI mulai dari struktur kurikulum sampai dengan Rencana Pembelajaran Semester (RPS) untuk tiap mata kuliah tapi KKNI belum dapat diterapkan saat ini. Prodi masih menunggu instruksi pimpinan universitas dalam bentuk surat keputusan rektor untuk menerapkan KKNI.

Hasil wawancara ke enam tentang Apa kelebihan KKNI dengan kurikulum sebelumnya, jawaban mereka sebenarnya KKNI adalah kurikulum yang menggunakan pendekatan luaran (outcome based approach). Untuk itu dalam pelaksanaannya juga digunakan pendekatan luaran ini dalam proses desain instruksional di masing-masing mata kuliah, bahwa perencanaan mata kuliah didasarkan pada capaian pembelajaran mata kuliah yang merupakan turunan dari capaian pembelajaran lulusan yang dibebankan pada suatu mata kuliah. Baru setelah itu dikaji bahan apa yang dapat menunjang pemenuhan capaian pembelajaran mata kuliah tersebut.

Hal ini berbeda dengan yang umumnya selama ini dilakukan bahwa perencanaan mata kuliah didasarkan pada materi berupa bahan ajar yang biasanya diadopsi dari suatu referensi semisal buku teks pada kurikulum lainnya. Pertanyaan ketujuh tentang kalau sudah, seperti apa implementasinya, dan kalau belum kenapa belum terlaksana, seperti yang sudah dijelaskan pada jawaban nomor 5, Prodi Pendidikan Matematika belum dapat menerapkan Kurikulum KKNI saat ini. Hal ini dikarenakan Prodi masih menunggu instruksi pimpinan universitas dalam bentuk surat keputusan rektor untuk menerapkan kurikulum KKNI sebagai dasar hukum perubahan kurikulum yang berlaku saat ini.

Implementasi kurikulum Kerangka Kualifikasi Nasionmal Indonesia ada tiga tahap yang perlu diperhatikan dalam penerapan KKNI ini, yaitu tahap perencanaan, pelaksanaan dan evaluasi.

1. Tahap perencanaan

Tahap ini prodi matematika sudah mempersiapkan dan merespon akan tuntutan kepentingan perubahan sebuah kurikulum yang lebih berorientasi kepada kepentingan para lulusan (mahasiswa) sebagai output dan pengguna dalam hal ini masyarakat, industri dan birokrasi. Ada beberapa kegiatan yang dilaksanakan pada tahap perencanaan ini yaitu membentuk tim diskusi (focus discussion) yang melibatkan para dosen di lingkungan prodi matematika, workshop yang menghadirkan para ahli kurikulum, sosialisasi hasil kepada tenaga pendidik dan dosen.

2. Tahap pelaksanaan

Tahap ini merupakan pembuktian dari perencaan yang sudah didiskusikan sebalumnya. Pada tahap ini telaksana agenda focus discussion dengan menghadirkan para ahli kurikulum untuk membahas tentang pentingnya perubahan kurikulum, dukungan teori, faktor yang berpengaruh terhadap perubahan kurikulum. Pada tahap ini pula kegiatan workshop dilaksanakan sebagai target atau sasaran workshopnya adalah sampai melahirkan dokumen secara tertulis tentang KKNI pendidikan matematika. 


\section{Tahap evaluasi}

Pada tahap ini ingin melihat apakah aspek yang akan direncanakan dan dilaksanakan, sudah sesuai dengan kebutuhan yang diinginkan. Tahap ini ingin memastikan apakah semua perangkat yang terkait dengan implementasi KKNI sudah betul-betul siap untuk diterapkan. Ada perbedaan kurikulum sebelumnya dengan KKNI dimana kurikulum ini menyempurnakan kurikulum sebelumnya. Kurikulum Berbasis Kompetensi adalah kurikulum yang beroreointasi pada kebutuhan mahasiswa terutama tentang keahlian apa yang akan mereka miliki setelah menyelesaikan salah satu jenjang pendidikan S1,S2 dan S3. Konsep ini masih bersifat luas dan umum cakupannya, maka perlu lebih difokuskan pencapaian kompetensinya, maka untuk menjawab kebutuhan tersebut maka lahirlah KKNI, sebagai jawaban kebutuhan para peserta didik yang pencapaian tujuan pembelajarannya lebih diarahkan kepada level 6 . Ada beberapa faktor yang menjadi penghambat implementasi kurikulum KKNI salah satunya adalah masih belum dipahaminya isi dan struktur kurikulum oleh para dosen, kurangnya sarana prasarana yang mendukung, sumber daya-manusia yang masih terbatas, serta waktu yang tersedia masih kurang dan yang paling penting adalah kebijakan pimpinan untuk mengambil keputusan. KKNI sangat sesuai dengan kebutuhan para mahasiswa sebagai output dari proses pembelajaran di perguruan tinggi. Para mahasiswa tidak hanya dibekali dengan sejumlah pengetahuan akan tetapi kemampuan mempraktekan pada tataran lapangan pekerjaan dengan siap, sehingga setiap lulusan perguruan tinggi bisa diterima baik oleh masyarakat, biroksi maupun industri.

\section{SIMPULAN DAN SARAN}

Implemenatasi kurikulum KKNI di prodi matematika, dilakukan melalui 3 tahap yaitu perencanaan, pelaksanaan dan tahap evaluasi. Hasil yang dapat dirumuskan dari ke 3 tahapan kegiatan tersebut dapat melahirkan dokumen KKNI. Pada tataran implementasi KKNI di prodi matematika belum berjalan secara baik, hal ini dikernakan sumber daya manusia yang belum mamahami, sarana prasarana yang kurang dan aspek kebijakan pimpinan yang belum mengeluarkan keputusan tentang berlakunya KKNI. Usaha yang dilakukan oleh pihak prodi melalui kegiatan worshop dan seminar, sosialisasi sampai pada tingkat implementasi dalam proses pembelajaran. saran yang bisa disampaikan sebagai tindak lanjut dari hasil penelitian ini yaitu pentingnya kepada dosen untuk mengikuti seminar, workshop dan sosialisasi KKNI bagi yang belum, sesuai dengan mata kuliah yang diampunya. Pimpinan Fakultas dan prodi sebagai pengambil kebijakan untuk segera ditindaklanjuti dalam pemberlakukan KKNI di lingkungan Fakultas Tarbiyah dan Keguruan UIN Raden Intan lampung khususnya prodi Matematika.

\section{DAFTAR PUSTAKA}

[1] E. Yuliasari, "Eksperimentasi Model PBL dan Model GDL Terhadap Kemampuan Pemecahan Masalah Matematis Ditinjau dari Kemandirian Belajar," JIPM J. Ilm. Pendidik. Mat., vol. 6, no. 1, pp. 1-10, 2017.

[2] S. Sukring, "Pendidik dalam Pengembangan Kecerdasan Peserta Didik (Analisis Perspektif Pendidikan Islam)," Tadris J. Kegur. Dan Ilmu Tarb., vol. 1, no. 1, pp. 57-68, 2016.

[3] D. W. Johnson and R. T. Johnson, "Cooperative Learning in 21st Century," Psicol Ann Psychol, vol. 30, no. 3, pp. 841-851, Aug. 2014.

[4] D. W. Johnson and R. T. Johnson, "Cooperative Learning in 21st Century," An. Psicol. Ann. Psychol., vol. 30, no. 3, pp. 841-851, Aug. 2014. 
[5] S. Widyawati, "Pengaruh Kemampuan Koneksi Matematis Siswa Terhadap Prestasi Belajar Matematika Ditinjau Dari Gaya Belajar Pada Materi Bangun Ruang Sisi Datar Siswa Kelas IX SMP di Kota Metro," Iqra J. Kaji. Ilmu Pendidik., vol. 1, no. 1, pp. 47-68, Mar. 2017.

[6] N. Gustini, "Bimbingan dan Konseling melalui Pengembangan Akhlak Mulia Siswa Berbasis Pemikiran Al-Ghazali," Tadris J. Kegur. Dan Ilmu Tarb., vol. 1, no. 1, pp. 1-14, 2016.

[8] K. Anwar, "Pendidikan Hukum Di Era Transisi Dalam Negara Demokrasi Menuju Indonesia Baru," Masal.-Masal. Huk., vol. 40, no. 2, pp. 236-245, 2011.

[9] I. Solikhah, "KKNI dalam Kurikulum Berbasis Learning Outcomes," LINGUA J. Lang. Lit. Teach., vol. 12, no. 1, pp. 1-22, 2015.

[10] W. Murtafiah and E. Suprapto, "Pengembangan Bahan Ajar Berorientasi Kkni Untuk Penguatan Scientific Approach Pada Mata Kuliah Evaluasi Dan Proses Pembelajaran Matematika," J. Penelit. Pendidik., vol. 8, no. 1, pp. 1245-1249, 2017.

[11] L. Sugiharto, “Alternatif Penyusunan Kurikulum Mengacu pada KKNI,” Dir. Jendral Pendidik. Tinggi, 2013.

[12] S. Akbar, "Penyegaran Pembelajaran Tematik Berbasis KKNI Kurikulum 2013: makalah kuliah umum," Malang Univ. Kanjuruban Malang, 2014.

[13] M. Sugiyono, Metode Penelitian Kuantitatif, Kualitatif, dan Kombinasi. Bandung: Alfabeta, 2012.

[14] J. Moleong, “Lexy. 2014, Metodologi Penelitian Kualitatif, Bandung: PT,” Remaja Rosdakarya. 